\title{
二自由度制御形並列多重磁気浮上の実現
}

\author{
成澤 慶宜*1, 水野 毅*2，高崎 正也*1，原 正之*11，山口 大介*1，石野 裕二*1
}

\section{Realization of two-degree-of-freedom motions control using parallel magnetic suspension}

\author{
Yoshinori NARISAWA ${ }^{* 1}$,Takeshi MIZUNO ${ }^{* 2}$, Masaya TAKASAKI*1, \\ Masayuki HARA*1 ${ }^{*}$ Daisuke YAMAGUCHI ${ }^{* 1}$ and Yuji ISHINO *1 \\ ${ }^{* 1,{ }^{*} 2}$ Department of Mechanical Engineering, Saitama University \\ 255 Shimoookubo, Sakura-ku, Saitama-shi, Saitama 338-8570, Japan
}

Received: 1 November 2016; Revised: 10 January 2017; Accepted: 6 March 2017

\begin{abstract}
Parallel magnetic suspension has been proposed which levitates multiple floators with a single power amplifier. This study applies this concept to a multi-degree-of-freedom system. In such systems, multiple electromagnets are used to stabilize multi-degree-of-freedom motions of the floator. In conventional system, each electromagnet is driven by the corresponding power amplifier. In contrast, multiple electromagnets are driven by a single power amplifier simultaneously in the case of parallel magnetic suspension. This study shows the feasibility of multi-degree-of-freedom control with a single power amplifier. First, the controllability of two-degree-of-freedom system controlled by parallel magnetic suspension is discussed. Second, an experimental apparatus is fabricated in which the vertical translational motion and the rotational motion around a horizontal axis are controlled by two pairs of electromagnets operated in a differential mode. Third, stable levitation is achieved in the apparatus. In addition, the dynamic characteristics are evaluated based on step response and frequency response with respect to external force. It is observed that the two suspended points vibrate in common phase with respect to the disturbance in a low-frequency region.
\end{abstract}

Key words : Magnetic bearing, Magnetic levitation, Mechatronics, Motion control, Parallel suspension, Two-degree-of-freedom system, Controllability

\section{1. 緒言}

電磁石の吸引力を利用した磁気浮上系では，能動的な制御によって安定化することにより，非接触で浮上体を 支持することができる，摩擦・磨耗のないシステムを構築できることから，接触支持部を磁気浮上に置き換える ことで振動・騒音の低減が可能であり，また粉塵の発生を抑えられることから真空中やクリーンルームなどの特 殊環境下での使用できるなど，磁気浮上を利用することで多くのメリットが得られる. 磁気浮上技術が応用され ている分野として，磁気軸受（Beams, 1951）やフライホイール（Henrikson et al., 1974） (Sabnis et al., 1975), 人工 心臓ポンプ（Masuzawa et al., 2002）などが挙げられる。このような吸引制御型磁気浮上システムは，基本的には 浮上対象となる物体（以下，浮上体と呼ぶ）が単一で，アクチュエータである電磁石が最小で一個，多自由度の 運動を制御する場合では複数個用いられる。 また，電磁石の励磁を行う電力増幅器（以下，アンプと呼ぶ）が電 磁石と同数必要となる。したがって，通常の磁気浮上系では電磁石と同数のアンプが必要となる．このため，複 数の電磁石を用いる磁気軸受などを用いる場合，多くのアンプを使用するため高価格になってしまう.

そこで著者らは，単一のアンプを用いて複数の浮上体を同時に制御する並列多重磁気浮上システムを提案して いる(水野他, 2010). 本システムを用いることにより，使用するアンプの数を減らすことができるので，コストの

\footnotetext{
No.16-00512 [DOI:10.1299/transjsme.16-00512], J-STAGE Advance Publication date: 31 March, 2017

*1 正員，埼玉大学（干338-8570 埼玉県さいたま市桜区下大久保 255）

*2 正員, フェロー, 埼玉大学

E-mail of corresponding author: mizar@mech.saitama-u.ac.jp
} 
低減や省スペース化などが期待できる，これまでに，電流出力型あるいは電圧出力型アンプを用いて実験的に二 つの浮上体の安定浮上を実現した例が報告されている（櫻田他, 2011）（Nishimura et al., 2011）（成澤他, 2012）。 た孫らにより，円盤磁石と回転モータを用いた可変磁路制御機構によって二つの鉄球の同時浮上を行う方式も提 案されており，浮上の実現が報告されている（孫，岡，2012）.

本研究は, これまでの多重式磁気浮上系とは異なり, 単一の浮上体の多自由度を支持する磁気浮上系を対象と する. 磁気軸受などでは, 浮上体の多自由度の運動の能動制御が行われる. そこで, 単一の浮上体に対して複数 の電磁石を持つシステムに多重式磁気浮上を適用することで, 単一のアンプによる多自由度支持の実現を目指し た. 関連する研究として, 岡らにより可変磁路制御形 2 自由度浮上機構を利用した棒の浮上が検討されている (岡 他, 2011). この方式では, コイルを持たない浮上系のため, 発熱の問題が無いというメリットがある反面, 機械 式制御のため高い応答速度では制御できないというデメリットがある. 本研究で提案している並列多重磁気浮上 を用いる方式では, 広く一般的に利用されている電磁石を用いた磁気浮上系に対して応用できる点がメリットと なる. さらに本研究では, 制御性能を向上寸る目的や, 微小重力環境での動作を目的として使用される差動型電 磁石を用いるシステムを対象とする．差動型電磁石を利用した 2 自由度の磁気浮上系では通常アンプを 4 台用い て制御が行われるが，本研究で提案する方式を適用することで，アンプ 1 台での制御が可能となる. 差動型電磁 石を用いるもう 1 つのメリットとして, バイアス磁束を調整することによって磁気浮上系の無制御でのダイナミ クスを変更できる点が挙げられる. したがって, 構造的に対称なシステムに並列多重磁気浮上を適用した場合に も，可制御性を満たすことが可能となる.

本稿では，鉛直並進運動及び水平軸周りの回転運動を制御する 2 自由度磁気浮上系を対象として，2 質点系の 物理モデルにおける可制御性を示す. 続いて, 構造的に対称な浮上体を, 差動型電磁石によって制御する実験装 置を製作し, 並列 2 重磁気浮上を実現したことを報告する. さらに, 浮上時のステップ応答及び周波数応答より, 動特性を評価する.

\section{2. 理論解析}

\section{$2 \cdot 1$ 基本方程式}

図 1 に示寸ような差動型の磁気浮上機構を考える. 今, 上下の電磁石は極性が反転するように直列接続されて いるとすると，それぞれに逆向きの制御電流 $i$ が流れると考えることができる. また，図 1 (b)に示すような永久 磁石によってバイアス磁束を与える磁気浮上系では, 磁気回路的には, 永久磁石の部分は空隙として考え, そこ に一定起磁力を加えることと等価になっている（電気学会 磁気浮上応用技術調査専門委員会 編, 1993). したが って, 図 1 (a)に示すようなバイアス電流 $I_{0}$ をちる磁気浮上系は, バイアス磁束の大きさを考慮すれば図 1 (b) に示すシステムと等価なものとして扱うことができる. 以降, 図 1 (a)に示寸モデルについて考える.

上側電磁石から発生する吸引力を $F_{U}$, 下側電磁石から発生する吸引力を $F_{L}$ とすると, この系の運動方程式は

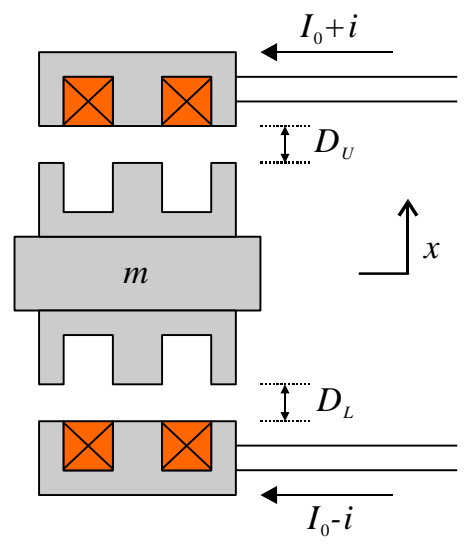

(a) without permanent magnet

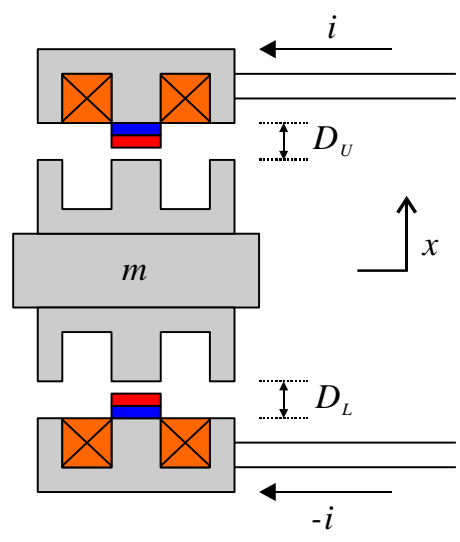

(b) with permanent magnet

Fig. 1 Models of differentially-operated magnetic suspension system. The bias flux is generated by bias current (a) or permanent magnet (b). Both systems can regard as equivalent system from a view point of the magnetic circuit. 
次式となる.

$$
m \ddot{x}=F_{U}-F_{L}-m g
$$

ここで,

$m$ : 浮上体質量

$x \quad$ : 変位

$g \quad$ : 重力加速度

上下の電磁石から発生する吸引力 $F_{U}, F_{L}$ を線形化すると,

$$
\begin{aligned}
& F_{U}=k_{U} \frac{\left(I_{0}+i\right)^{2}}{\left(D_{U}-x\right)^{2}}=k_{U} \frac{I_{0}{ }^{2}}{D_{U}{ }^{2}}+2 k_{U} \frac{I_{0}{ }^{2}}{D_{U}{ }^{3}} x+2 k_{U} \frac{I_{0}}{D_{U}{ }^{2}} i=F_{0 U}+k_{s U} x+k_{i U} i \\
& F_{L}=k_{L} \frac{\left(I_{0}-i\right)^{2}}{\left(D_{L}+x\right)^{2}}=k_{L} \frac{I_{0}{ }^{2}}{D_{L}{ }^{2}}-2 k_{L} \frac{I_{0}{ }^{2}}{D_{L}{ }^{3}} x-2 k_{L} \frac{I_{0}}{D_{L}{ }^{2}} i=F_{0 L}-k_{s L} x-k_{i L} i
\end{aligned}
$$

と表せる.ここで，

$$
\begin{array}{ll}
D_{U} & : \text { 浮上体-上側電磁石間ギャップ } \\
D_{L} & : \text { 浮上体-下側電磁石間ギャップ } \\
k_{U}, k_{L} & : \text { 電磁石吸引力係数 } \\
F_{0 U}, F_{0 L} & : \text { 電磁石の定常的な支持力 } \\
k_{S U}, k_{s L} & : \text { 電磁石特性係数 (力 } / \text { 変位 }) \\
k_{i U}, k_{s L} & : \text { 電磁石特性係数 (力 } / \text { 電流) }
\end{array}
$$

式(1)に代入すると，

$$
m \ddot{x}=F_{0 U}-F_{0 L}+\left(k_{s U}+k_{s L}\right) x+\left(k_{i U}+k_{i L}\right) i-m g \equiv F_{0}+k_{s} x+k_{i} i-m g
$$

となる、いま，静的な力の釣り合いにより

$$
F_{0}=m g
$$

が成り立っていると考えると，差動型磁気浮上系の運動方程式は次式で表せる．

$$
m \ddot{x}=k_{s} x+k_{i} i
$$

\section{$2 \cdot 22$ 自由度制御形磁気浮上系}

図 2 に示すようなモデルを考える．浮上体は，二つの質量が質量の無視できる棒で繋がれたダンベル形状であ るとする．電磁石はすべて同じ特性を持つものが直列に接続されており，上側と下側では結線の方向を変え，同 じ電流に対して極性が逆向きになっているとする．以下，右側の磁気浮上機構を第 1 支持部，もう一方を第 2 支

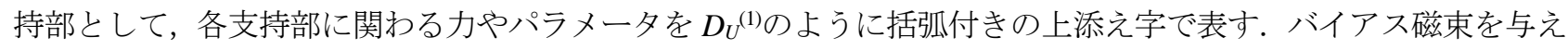
る永久磁石は磁路と同じ断面積を持っており，上下では厚みが同じで，左右では異なっているとする．以下では 簡単のため, 第 1 支持部の永久磁石が第 2 支持部の永久磁石よりも厚みが大きいとする. まとめると, 浮上体の 重心位置を中心として，上下方向に対称であり，また永久磁石を除いて左右方向に対称な構造となっている.

運動方程式は以下の 2 式となる.

$$
\begin{aligned}
& m \ddot{x}=F_{0}^{(1)}+F_{0}^{(2)}+k_{s}^{(1)}(L \theta+x)+k_{s}^{(2)}(-L \theta+x)+\left(k_{i}^{(1)}+k_{i}^{(2)}\right) i \\
& I_{r} \ddot{\theta}=L F_{0}^{(1)}-L F_{0}^{(2)}+L k_{s}^{(1)}(L \theta+x)-L k_{s}^{(2)}(-L \theta+x)+\left(L k_{i}^{(1)}-L k_{i}^{(2)}\right) i
\end{aligned}
$$


ここで,

$m$ : 浮上体質量

$x \quad$ : 重心位置における変位

$\theta \quad$ : 角変位

$L \quad$ : 支持部-重心間距離

$I_{r} \quad:$ 重心周りの慣性モーメント

$i \quad:$ 制御電流

$g \quad:$ 重力加速度

$F_{0}^{(n)} \quad:$ 第 $n$ 支持部電磁石の定常的な支持力

$k_{s}^{(n)} \quad:$ 第 $n$ 支持部電磁石特性係数 (力 $/$ 変位)

$k_{i}^{(n)} \quad:$ 第 $n$ 支持部電磁石特性係数 (力 $/$ 電流)

$D_{U}^{(n)} \quad:$ 第 $n$ 支持部の浮上体-上側電磁石間ギャップ

$D_{L}^{(n)} \quad$ : 第 $n$ 支持部の浮上体-下側電磁石間ギャップ

静的な力の釣り合い，モーメントの釣り合いから，

$$
\begin{aligned}
& F_{0}^{(1)}+F_{0}^{(2)}=m g \\
& L F_{0}^{(1)}-L F_{0}^{(2)}=0
\end{aligned}
$$

が成り立っているとする．またこの系の慣性モーメントは,

$$
I_{r}=\frac{m}{2} L^{2}+\frac{m}{2} L^{2}=m L^{2}
$$

と表せる．状態方程式は次式となる。

$$
\frac{d}{d t}\left[\begin{array}{c}
x \\
\dot{x} \\
\theta \\
\dot{\theta}
\end{array}\right]=\left[\begin{array}{cccc}
0 & 1 & 0 & 0 \\
\frac{k_{s}^{(1)}+k_{s}^{(2)}}{m} & 0 & \frac{\left(k_{s}^{(1)}-k_{s}^{(2)}\right) L}{m} & 0 \\
0 & 0 & 0 & 1 \\
\frac{k_{s}^{(1)}-k_{s}^{(2)}}{m L} & 0 & \frac{k_{s}^{(1)}+k_{s}^{(2)}}{m} & 0
\end{array}\right]\left[\begin{array}{l}
x \\
\dot{x} \\
\theta \\
\dot{\theta}
\end{array}\right]+\left[\begin{array}{c}
0 \\
\frac{k_{i}^{(1)}+k_{i}^{(2)}}{m} \\
0 \\
\frac{k_{i}^{(1)}-k_{i}^{(2)}}{m L}
\end{array}\right] i
$$

\section{$2 \cdot 3$ 可制御性}

可制御性行列 $\boldsymbol{M}_{C}$ は次式で表される.

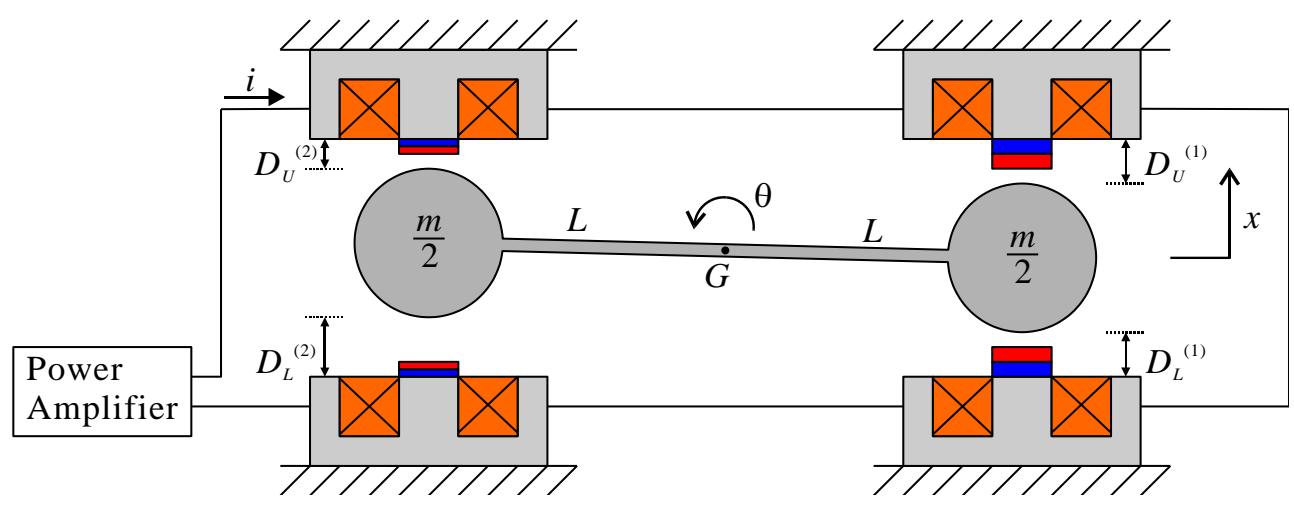

Fig. 2 Model of differentially-operated current-controlled two-degree-of-freedom parallel magnetic suspension system. The floator consists of two masses connected by a massless bar. Both magnetic suspension systems are constructed symmetrically except the size of permanent magnet. 


$$
\boldsymbol{M}_{C}=\left[\begin{array}{cccc}
0 & \frac{k_{i}^{(1)}+k_{i}^{(2)}}{m} & 0 & \frac{2\left(k_{s}^{(1)} k_{i}^{(1)}+k_{s}^{(2)} k_{i}^{(2)}\right)}{m^{2}} \\
\frac{k_{i}^{(1)}+k_{i}^{(2)}}{m} & 0 & \frac{2\left(k_{s}^{(1)} k_{i}^{(1)}+k_{s}^{(2)} k_{i}^{(2)}\right)}{m^{2}} & 0 \\
0 & \frac{k_{i}^{(1)}-k_{i}^{(2)}}{m L} & 0 & \frac{2\left(k_{s}^{(1)} k_{i}^{(1)}-k_{s}^{(2)} k_{i}^{(2)}\right)}{m^{2} L} \\
\frac{k_{i}^{(1)}-k_{i}^{(2)}}{m L} & 0 & \frac{2\left(k_{s}^{(1)} k_{i}^{(1)}-k_{s}^{(2)} k_{i}^{(2)}\right)}{m^{2} L} & 0
\end{array}\right]
$$

式(13)の行列式を計算すると,

$$
\operatorname{det} \boldsymbol{M}_{C}=\frac{16\left(k_{i}^{(1)}\right)^{2}\left(k_{i}^{(2)}\right)^{2}\left(k_{s}^{(2)}-k_{s}^{(1)}\right)^{2}}{m^{6} L^{2}}
$$

となる.したがって，

$$
k_{s}^{(1)} \neq k_{s}^{(2)}
$$

の条件が満たされるとき，式(12)で動特性が表されるシステムは可制御となる． $k_{s}^{(n)}$ は電磁石の持つ負の剛性を 表しており，式(15)は各支持部の無制御でのダイナミクスがそれぞれで異なっている場合に可制御となることを 示している.

式(15)で表される条件について詳しく考える．式(9)，(10)より，

$$
2 F_{0}^{(n)}=m g
$$

が静的に安定する条件である．ここで，定常的な支持力は定義より次式のように変形できる.

$$
2 F_{0}^{(n)}=2 k_{U} \frac{\left(I_{0}^{(n)}\right)^{2}}{\left(D_{U}^{(n)}\right)^{2}}-2 k_{L} \frac{\left(I_{0}^{(n)}\right)}{\left(D_{L}^{(n)}\right)^{2}}=D_{U}^{(n)} k_{s U}^{(n)}-D_{L}^{(n)} k_{s L}^{(n)}
$$

コイルに流れる電流が零のとき，浮上体には上下の永久磁石による吸引力及び重力だけが働く，磁気力は浮上体 の位置が差動型電磁石間の中心にあるとき，すなわち上下のギャップが等しくなるときに零となる．このときの ギャップを $D_{0}$ とし，重力との釣り合いを考えると各ギャップと $D_{0}$ の関係は,

$$
D_{U}^{(n)}<D_{0}<D_{L}^{(n)}
$$

と表せる，そこで，各ギャップを次式を用いて近似する．

$$
\begin{aligned}
& D_{U}^{(n)}=D_{0}-d^{(n)} \\
& D_{L}^{(n)}=D_{0}+d^{(n)}
\end{aligned}
$$

ここで， $d^{(n)}$ は第 $n$ 支持部の差動型電磁石間の中心から平衡点までの距離である. 式(17)の右辺を式(19),(20)を用 いて整理すると，

$$
D_{U}^{(n)} k_{s U}^{(n)}-D_{L}^{(n)} k_{s L}^{(n)}=\left(D_{0}-d^{(n)}\right) k_{s U}^{(n)}-\left(D_{0}+d^{(n)}\right) k_{s L}^{(n)}=-2 d^{(n)}\left(k_{s U}^{(n)}+k_{s L}^{(n)}\right)=-2 d^{(n)} k_{s}^{(n)}
$$


したがって式(16)より，

$$
k_{s}^{(n)}=-\frac{m g}{2 d^{(n)}}
$$

と表せる. 式(14)を式(22)を用いて整理すると，

$$
\operatorname{det} \boldsymbol{M}_{C}=\frac{16\left(k_{i}^{(1)}\right)^{2}\left(k_{i}^{(2)}\right)^{2} m^{2} g^{2}\left(\frac{1}{d^{(1)}}-\frac{1}{d^{(2)}}\right)^{2}}{m^{6} L^{2}}
$$

よって，式(12)で動特性が示されるシステムが可制御であるとき，定常的に

$$
d^{(1)} \neq d^{(2)}
$$

となることが分かる. よって図 2 に示されるシステムでは，安定浮上時に各支持部におけるギャップが異なって いることが分かる.

なお，式(24)は浮上体に重力が働く場合に成り立つものである。ここからは，重力の影響がない場合，例とし て図 2 を 90 度回転させ, 浮上体のラジアル方向のみの磁気支持を行う場合を考える. 差動型電磁石を用いている ため，この場合にも平衡点を持ち，制御が可能である．力の釣り合いとモーメントの釣り合いは，

$$
\begin{aligned}
& F_{0}^{(1)}+F_{0}^{(2)}=0 \\
& L F_{0}^{(1)}-L F_{0}^{(2)}=0
\end{aligned}
$$

となることから，

$$
F_{0}^{(1)}=F_{0}^{(2)}=0
$$

となる．式(17)，(27)より，

$$
D_{U}^{(n)} k_{s U}^{(n)}-D_{L}^{(n)} k_{s L}^{(n)}=0
$$

が静的な釣り合い条件となる．式(28)は，

$$
D_{U}^{(n)}=D_{L}^{(n)}=D_{0}
$$

の条件下でも成り立つ. 重力の影響が無い場合には, ギャップ $D_{0}$ の位置で浮上体に働く力が釣り合うためである. またこのとき，各支持部でのバイアス磁束の大きさは変更可能であるため，可制御性を満たす条件が存在する. したがって, 差動型電磁石を利用したシステムであり, かつ重力の影響がない場合には各支持部のギャップが等 しいときにも安定浮上が可能である.

一方で，図 2 に示したような重力が働く場合においても，差動型電磁石のバイアス磁束を上下で差をつけるこ とで，各支持部の浮上ギャップを等しくすることが可能である．例えば，第 1 支持部の下側電磁石のバイアス磁 束を大きくすることで，平衡点は上方向に変化するため，これが第 2 支持部の平衡点でのギャップに一致するよ う調節することで実現できる. このとき， $k_{s}^{(1)}$ は同時に増加するため, 各支持部の $k_{s}^{(n)}$ の差も増加することから, 可制御性を満たすことは明らかである. しかし，重力の影響がない場合では各支持部のギャップに差が生じるこ とに注意を要する. 


\section{$2 \cdot 4$ 同値変換}

式(12)の状態変数に着目する. 第 $n$ 支持部における変位を $x^{(n)}$ とすれば,

$$
\begin{aligned}
& x^{(1)}=L \theta+x \\
& x^{(2)}=-L \theta+x
\end{aligned}
$$

が成り立つため, 次式の関係が成り立つ.

$$
\left[\begin{array}{c}
x \\
\dot{x} \\
\theta \\
\dot{\theta}
\end{array}\right]=\left[\begin{array}{cccc}
\frac{1}{2} & 0 & \frac{1}{2} & 0 \\
0 & \frac{1}{2} & 0 & \frac{1}{2} \\
\frac{1}{2 L} & 0 & -\frac{1}{2 L} & 0 \\
0 & \frac{1}{2 L} & 0 & -\frac{1}{2 L}
\end{array}\right]\left[\begin{array}{c}
x^{(1)} \\
\dot{x}^{(1)} \\
x^{(2)} \\
\dot{x}^{(2)}
\end{array}\right] \equiv \boldsymbol{T}\left[\begin{array}{c}
x^{(1)} \\
\dot{x}^{(1)} \\
x^{(2)} \\
\dot{x}^{(2)}
\end{array}\right]
$$

したがって，式(12)は正則行列 $T$ を用いて同值変換が可能であり，次式のように表せる.

$$
\frac{d}{d t}\left[\begin{array}{c}
x^{(1)} \\
\dot{x}^{(1)} \\
x^{(2)} \\
\dot{x}^{(2)}
\end{array}\right]=\left[\begin{array}{cccc}
0 & 1 & 0 & 0 \\
\frac{2 k_{s}^{(1)}}{m} & 0 & 0 & 0 \\
0 & 0 & 0 & 1 \\
0 & 0 & \frac{2 k_{s}^{(2)}}{m} & 0
\end{array}\right]\left[\begin{array}{c}
x^{(1)} \\
\dot{x}^{(1)} \\
x^{(2)} \\
\dot{x}^{(2)}
\end{array}\right]+\left[\begin{array}{c}
0 \\
\frac{2 k_{i}^{(1)}}{m} \\
0 \\
\frac{2 k_{i}^{(2)}}{m}
\end{array}\right] i \equiv\left[\begin{array}{cccc}
0 & 1 & 0 & 0 \\
a^{(1)} & 0 & 0 & 0 \\
0 & 0 & 0 & 1 \\
0 & 0 & a^{(2)} & 0
\end{array}\right]\left[\begin{array}{c}
x^{(1)} \\
\dot{x}^{(1)} \\
x^{(2)} \\
\dot{x}^{(2)}
\end{array}\right]+\left[\begin{array}{c}
0 \\
b^{(1)} \\
0 \\
b^{(2)}
\end{array}\right] i
$$

ここで,

$$
\begin{aligned}
a^{(n)} & =\frac{2 k_{s}^{(n)}}{m} \\
b^{(n)} & =\frac{2 k_{i}^{(n)}}{m}
\end{aligned}
$$

である. 式(33)は従来の多重磁気浮上系と同じ状態方程式で記述することが可能であり，各支持部における变位 と速度を用いた状態フィードバックを行った場合でも制御が可能であることを示している（水野他，2010）。

\section{$2 \cdot 5$ 閉ループ系の安定性}

式(33)で動特性が示されるシステムは,

$$
a^{(1)} \neq a^{(2)}
$$

のとき可制御であるため, 次式に示すような状態フィードバックにより安定化が可能である.

$$
i=-\left(p_{d}^{(1)} x^{(1)}+p_{v}^{(1)} \dot{x}^{(1)}+p_{d}^{(2)} x^{(2)}+p_{v}^{(2)} \dot{x}^{(2)}\right)
$$

ここで， $p_{d}^{(n)}$ は変位フィードバックゲイン， $p_{v}^{(n)}$ は速度フィードバックゲインである．並列二重磁気浮上では， 経験的に第 1 支持部の変位と速度のフィードバック係数と, 第 2 支持部の変位と速度のフィードバック係数が異 符合にならないと安定な浮上が達成できないことがわかっている. 本節では, 安定条件からフィードバックゲイ ンの符号について考察する. 式(33)で示されるシステムに対して, 式(37)で示される状態フィードバックを適用し た閉ループ系の特性多項式 $\phi(s)$ を次式のように表す.

$$
\phi(s)=s^{4}+\alpha_{3} s^{3}+\alpha_{2} s^{2}+\alpha_{1} s+\alpha_{0}
$$


ここで，各係数は，

$$
\begin{aligned}
& \alpha_{3}=b^{(1)} p_{v}^{(1)}+b^{(2)} p_{v}^{(2)} \\
& \alpha_{2}=b^{(1)} p_{d}^{(1)}-a^{(1)}+b^{(2)} p_{d}^{(2)}-a^{(2)} \\
& \alpha_{1}=-a^{(2)} b^{(1)} p_{v}^{(1)}-a^{(1)} b^{(2)} p_{v}^{(2)} \\
& \alpha_{0}=-a^{(2)} b^{(1)} p_{d}^{(1)}-a^{(1)} b^{(2)} p_{d}^{(2)}+a^{(1)} a^{(2)}
\end{aligned}
$$

である. 安定性の必要条件より, システムが安定となる場合には全ての係数が正とならなければならない. 式(39), (41)より， $\alpha_{3}$ 及び $\alpha_{1}$ がどちらも正になるためには $p_{v}^{(1)}$ と $p_{v}^{(2)}$ は異符号でなくてはならないことがわかる.ここで,

$$
a^{(1)}>a^{(2)}
$$

が成立していると仮定する．式(41)を変形すると，

$$
\alpha_{1}=-a^{(2)}\left(b^{(1)} p_{v}^{(1)}+b^{(2)} p_{v}^{(2)}\right)-\left(a^{(1)}-a^{(2)}\right) b^{(2)} p_{v}^{(2)}=-a^{(2)} \alpha_{3}-\left(a^{(1)}-a^{(2)}\right) b^{(2)} p_{v}^{(2)}
$$

となるため, $\alpha_{3}$ 及び $\alpha_{1}$ がどちらも正になるためには， $b^{(2)}$ が正のとき $p_{v}^{(2)}$ が負の值でなくてはならないことがわ かる. したがって, $p_{v}^{(1)}$ は正の值となる.

続いて，式(42)を変形すると，

$$
\alpha_{0}=-a^{(2)}\left(b^{(1)} p_{d}^{(1)}-a^{(1)}\right)-a^{(1)}\left(b^{(2)} p_{d}^{(2)}-a^{(2)}\right)-a^{(1)} a^{(2)}
$$

ここで,

$$
b^{(2)} p_{d}^{(2)}-a^{(2)}>0
$$

と仮定し，式(45)右辺に $\left(a^{(1)}-a^{(2)}\right)$ 倍して加えると，

$$
\alpha_{0}<-a^{(2)}\left(b^{(1)} p_{d}^{(1)}-a^{(1)}+b^{(2)} p_{d}^{(2)}-a^{(2)}\right)-a^{(1)} a^{(2)}=-a^{(2)} \alpha_{2}-a^{(1)} a^{(2)}
$$

となる．この式から， $\alpha_{2}$ が正のとき， $\alpha_{0}$ は負となり，安定性の必要条件が満たされない. したがって， $\alpha_{2}$ 及び $\alpha_{0}$ が正となるためには,

$$
b^{(2)} p_{d}^{(2)}-a^{(2)}<0
$$

でなくてはならないため， $p_{d}^{(2)}$ は負の值となる．またこのとき，式(40)より， $\alpha_{2}$ が正となるためには， $b^{(1)}$ が正 のとき， $p_{d}^{(1)}$ が正の值でなくてはならないことがわかる.

まとめると，

$$
b^{(1)}>0, b^{(2)}>0
$$

のとき，閉ループ系が安定となるためには，

$$
a^{(1)}>a^{(2)}
$$


ならば,

$$
p_{d}^{(1)}>0, \quad p_{v}^{(1)}>0, \quad p_{d}^{(2)}<0, \quad p_{v}^{(2)}<0
$$

が成立しなければならない。逆に，

$$
a^{(1)}<a^{(2)}
$$

ならば,

$$
p_{d}^{(1)}<0, \quad p_{v}^{(1)}<0, \quad p_{d}^{(2)}>0, \quad p_{v}^{(2)}>0
$$

が成立しなければならない. よって, 式(33)で動特性が表される並列多重磁気浮上システムに対して, 式(37)に示 す状態フィードバックを適用する場合, 特性係数 $a^{(n)}$ の大きい支持部に関わる状態変数を負帰還, もう一方を正 帰還することがシステムが安定となる必要条件である.

\section{3. 実験装置}

製作した磁気浮上装置の写真を図 3 (a)(b)に，概念図を図 3 (c)に示す。浮上体は長さ $480 \mathrm{~mm}$ のアルミ丸棒に, 電磁石及び渦電流式変位センサのターゲットとなる軟鉄が重心位置を対称にして取り付けられた構成となってお り, 浮上体全体の質量は $0.341 \mathrm{~kg}$ である. 電磁石は 2 組の差動型構造となっており, 浮上体を 2 点で支持する. これにより，鋁直並進運動及び水平軸周りの回転運動を制御する 2 自由度磁気浮上装置となっている. 浮上体の 重心位置には板ばねが取り付けられており，その他の自由度の運動を拘束している．板ばねの剛性は，制御する 並進及び回転方向に対して十分に小さく，無制御では不安定な状態となっている．各電磁石には異なるサイズの 永久磁石を取り付けており, 第 1 支持部には $15 \times 15 \times 4 \mathrm{~mm}$, 第 2 支持部には $15 \times 15 \times 1 \mathrm{~mm}$ のネオジム磁石が磁 路へ挿入されている. 各支持部におけるバイアス磁束に差をつけることで，式(15)で示される可制御性を満たし ている. また，第 2 支持部の電磁石はコイルが 2 段に巻かれており，一方は磁気支持，もう一方は外乱入力用と して使用した．各電磁石の電気的特性及び電磁石特性係数を表 1 にまとめる. 電磁石に関わる係数は対向する電 磁石ターゲットの距離に依存するが, これらは全て安定浮上時にバイアス電流がほぼ零となる位置において測定 した．このときの位置は，ゼロパワー制御を適用した際の浮上位置とした（Morishita el al.,1989）.

\section{4. 浮上実験}

\section{$4 \cdot 1$ 実験構成}

浮上用電磁石を全て直列接続し，電流制御型のアンプを用いて制御を行った．制御対象は式(33)で動特性が示 されるシステムとし，コントローラは各支持部の変位と速度を用いて状態フィードバックを行う構成とした。 こ

\begin{tabular}{|c|c|c|c|c|c|c|}
\hline & & & Inductance $[\mathrm{mH}]$ & Resistance $[\Omega]$ & $k_{s} \quad[\mathrm{~N} / \mathrm{m}]$ & $k_{i} \quad[\mathrm{~N} / \mathrm{A}]$ \\
\hline \multirow{4}{*}{ For control } & \multirow{2}{*}{$\begin{array}{c}\text { 1st suspension system } \\
\text { (Right) }\end{array}$} & Upper & 18.2 & 3.32 & \multirow{2}{*}{$5.94 \times 10^{3}$} & \multirow{2}{*}{3.60} \\
\hline & & Lower & 18.1 & 4.08 & & \\
\hline & \multirow{2}{*}{$\begin{array}{l}\text { 2nd suspension system } \\
\text { (Left) }\end{array}$} & Upper & 3.47 & 1.17 & \multirow{2}{*}{$1.21 \times 10^{3}$} & \multirow{2}{*}{0.88} \\
\hline & & Lower & 3.12 & 1.26 & & \\
\hline \multirow{2}{*}{ For disturbance } & \multirow{2}{*}{ 2nd suspension system } & Upper & 3.52 & 1.50 & \multirow{2}{*}{$1.22 \times 10^{3}$} & \multirow{2}{*}{0.89} \\
\hline & & Lower & 3.11 & 0.98 & & \\
\hline
\end{tabular}
のときのブロック線図を図 4 に示す.

Table 1 Characteristic coefficient of electromagnets. 


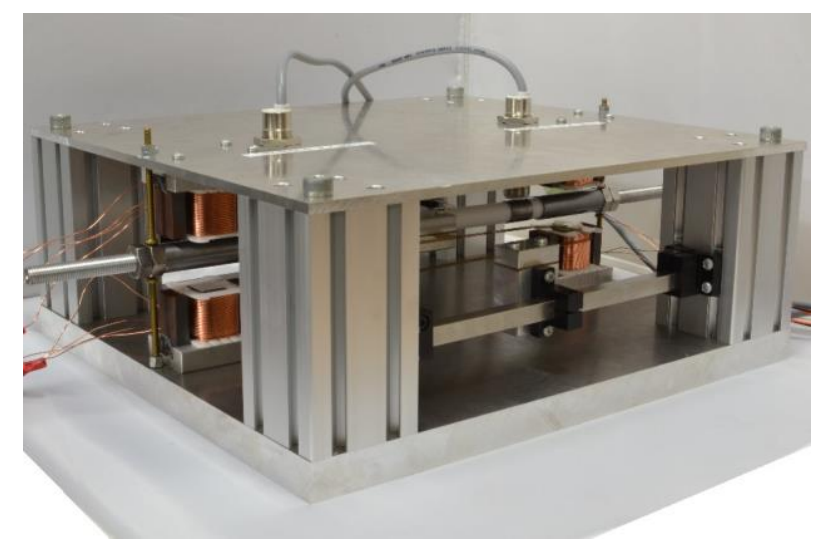

(a) Photograph - outside view -.

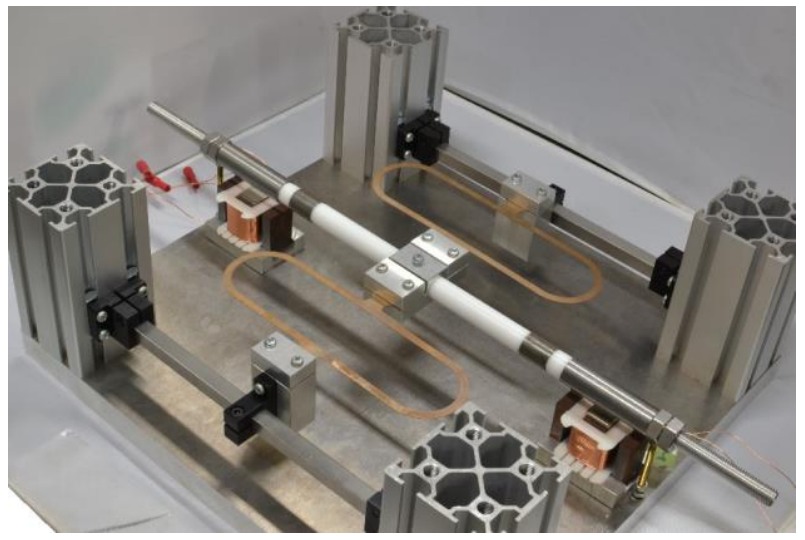

(b) Photograph - inside view -.

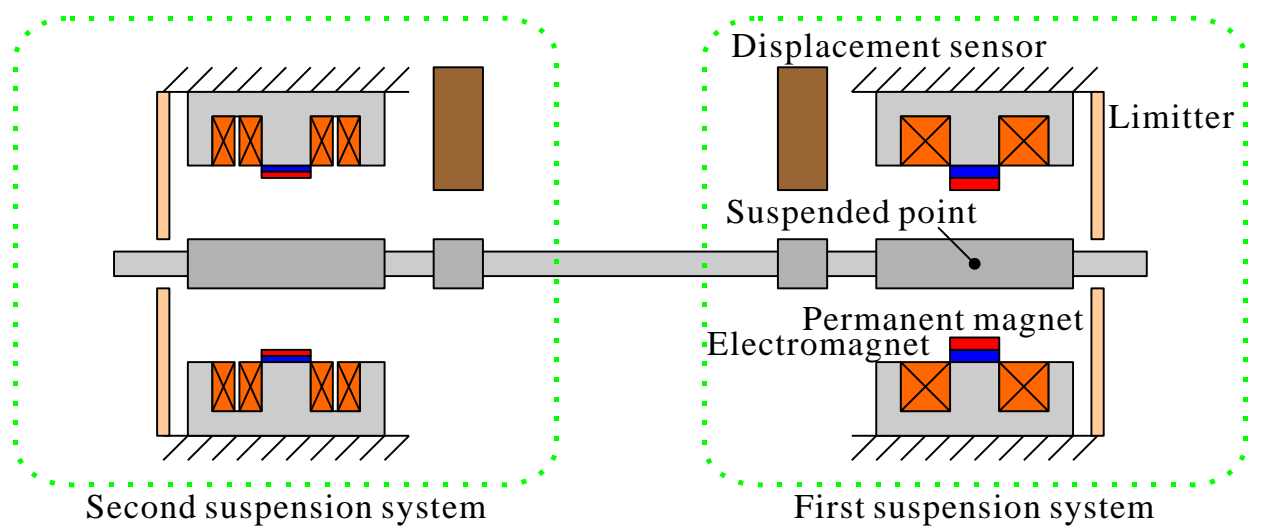

(c) Schematic view.

Fig. 3 Fabricated experimental apparatus. The subsystem with larger permanent magnet is named as the first suspension system (in the right), and the other is as the second suspension system (in the left).

\section{$4 \cdot 2$ ステップ応答}

2.5 節で示したフィードバックゲインの符号に注意しながら試行錯誤的にゲインチューニングを行い, 表 2 に示 すフィードバックゲインにおいて安定浮上を実現した．このとき，第 2 支持部の外乱用電磁石にステップ信号を 入力し，ステップ応答を取得した．外乱の振幅は $50 \mathrm{mN}$ となるように電流を調整した. 応答を図 5 に示寸. 片側 の支持部にのみ外乱を入力した場合にも，もう一方の支持部が同位相で振動する様子が見られる．これは従来の 並列多重磁気浮上系においても見られた特性であり，この系において並列多重磁気浮上が実現されていることを 示すものである. 振幅比は第 1 支持部に比べて第 2 支持部が $10 \%$ 程度大きい. 電磁石の接続は，制御電流が正の 
Narisawa, Mizuno, Takasaki, Hara, Yamaguchi and Ishino,

Transactions of the JSME (in Japanese), Vol.83, No.848 (2017)

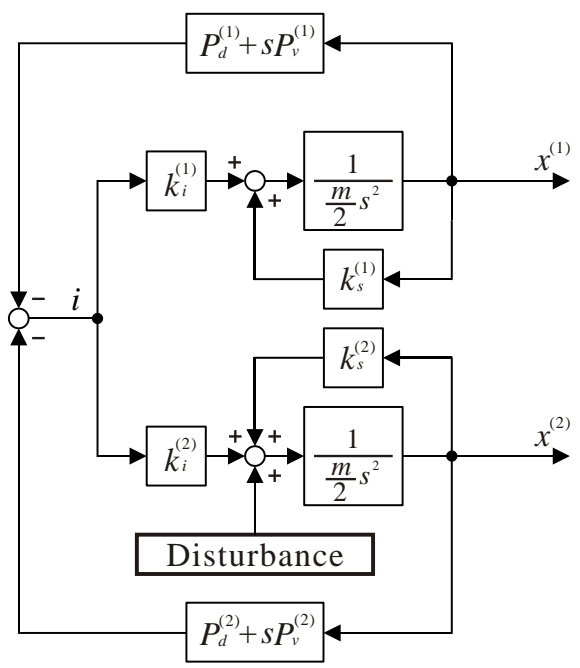

Fig. 4 Block diagram of the control system. The controller is constructed based on the state equation given by Eq. (33).

Table 2 Feedback gains in measuring step responses.

\begin{tabular}{c|c|c|c|c}
\hline \hline Parameters & $p_{d}^{(1)}[\mathrm{A} / \mathrm{m}]$ & $p_{v}^{(1)}[\mathrm{As} / \mathrm{m}]$ & $p_{d}^{(2)}[\mathrm{A} / \mathrm{m}]$ & $p_{v}^{(2)}[\mathrm{As} / \mathrm{m}]$ \\
\hline Value & $3.15 \times 10^{3}$ & 20 & $-1.35 \times 10^{3}$ & -25 \\
\hline
\end{tabular}

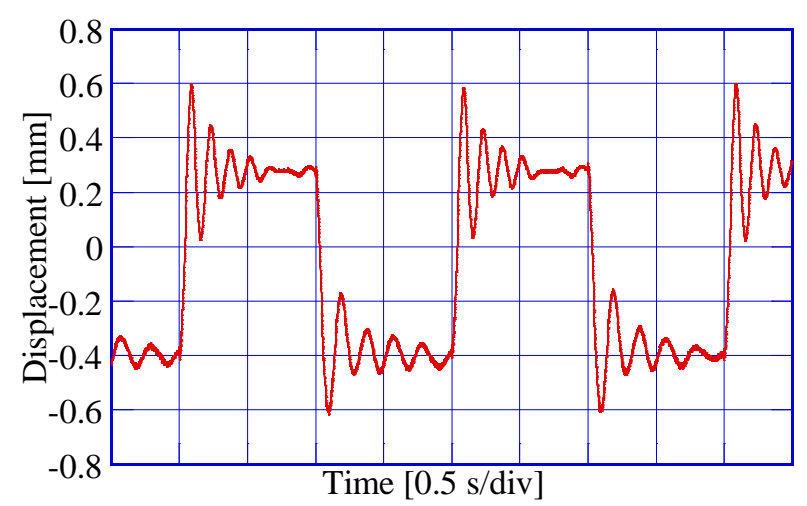

(a) Displacement of the 1st suspended point

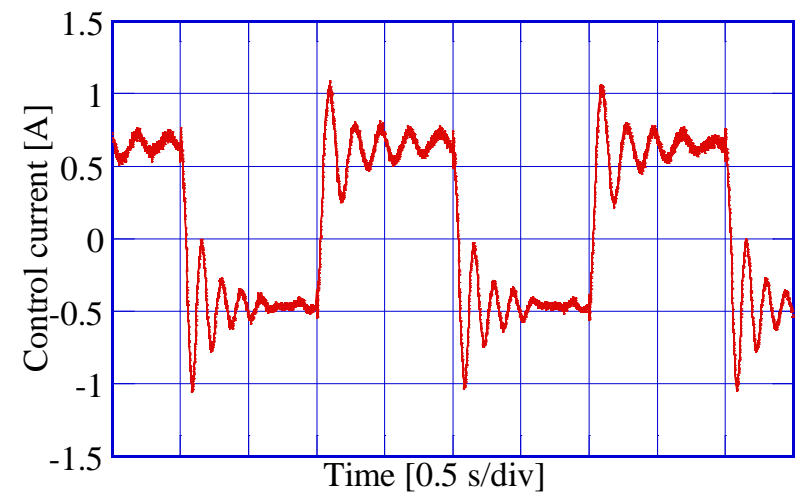

(c) Control current

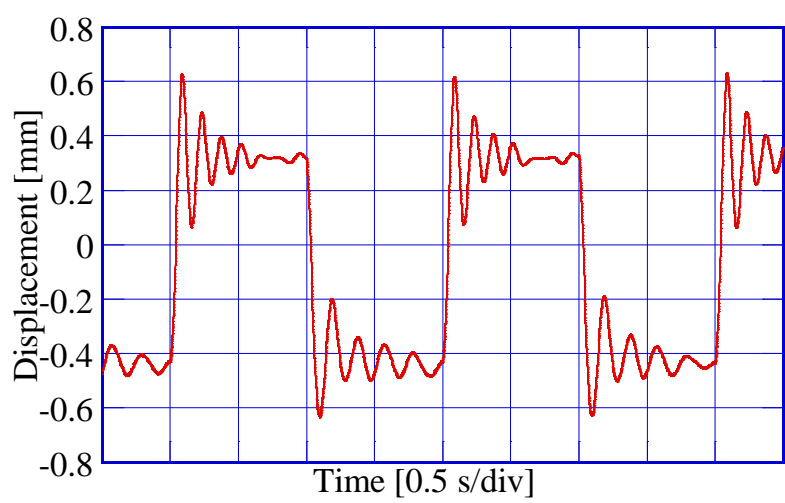

(b) Displacement of the 2nd suspended point

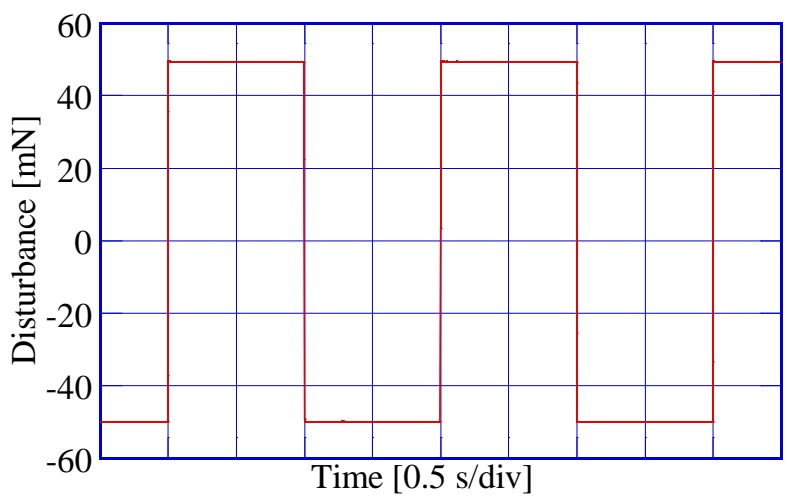

(d) Disturbance

Fig. 5 Step responses. Both suspended points move in the same direction as the disturbance even though it acts second suspended point solely. 
ときに上向きの力が増加する方向となるように結線してあるため，浮上体の変位に合わせて制御電流が平衡状態 を保つように変化していることが確認できる．また外乱は上向きの力が正となるように定義しており，入力され た外乱と同じ向きに浮上体が変位していることが分かる．以上のことから，表 2 に示されるような正帰還を含ん だコントローラであっても，この系は正の剛性を持つことが分かる. しかしながら，ステップ応答では行き過ぎ 量が大きく減衰特性がそれほどよくないことがわかる，これを改善するにはフィードバックゲインをより大きく 寸ればよいが，実際にはこれ以上大きくすると，コイルから高い音が発生するようになる．さらに，上側に変位 するときと下側に変位するときの応答に差があり，上側の振動が速く減衰する様子が見られる．これは，浮上位 置の変化によって電磁石特性係数が変化し, 浮上体の運動特性が変化しているものと推察される.

\section{$4 \cdot 3$ 周波数応答}

第 2 支持部の外乱用電磁石に正弦波状の信号を入力し，外乱に対する各磁気支持部の変位に関寸る周波数応答 を取得した. 外乱の振幅は $10 \mathrm{mN}$ となるように電流を調節した. 用いたフィードバックゲインを表 3 に，応答を 図 6 に示す．ゲイン線図では，外乱 $1 \mathrm{~N}$ に対して変位 $1 \mathrm{~mm}$ となるときを $0 \mathrm{~dB}$ と定義している. 本システムは 2 次系であるため, $7.3 \mathrm{~Hz}$ 及び $27.3 \mathrm{~Hz}$ に二つの共振周波数を持つ. ゲイン線図より, 一つ目の共振周波数では各 応答に差は見られないが，二つ目の共振周波数では第 1 支持部の応答に比べて第 2 支持部が $12 \mathrm{~dB}$ 低くなってい ることが分かる．位相線図に着目すると，どちらの支持部も共振の影響により $180 \mathrm{deg}$ の位相遅れが 2 度発生し ていることがわかる．また，外乱に対する各支持部の応答は $30 \mathrm{~Hz}$ 以下の低い周波数帯域では同位相となってい ることが観測された．これは，各コイルに流れる電流が，常に同位相であることに起因すると考えられる．以上

Table 3 Feedback gains in measuring frequency responses.

\begin{tabular}{c|c|c|c|c}
\hline \hline Parameters & $p_{d}^{(1)}[\mathrm{A} / \mathrm{m}]$ & $p_{v}^{(1)}[\mathrm{As} / \mathrm{m}]$ & $p_{d}^{(2)}[\mathrm{A} / \mathrm{m}]$ & $p_{v}^{(2)}[\mathrm{As} / \mathrm{m}]$ \\
\hline Value & $2.8 \times 10^{3}$ & 2 & $-1.1 \times 10^{3}$ & -2 \\
\hline
\end{tabular}
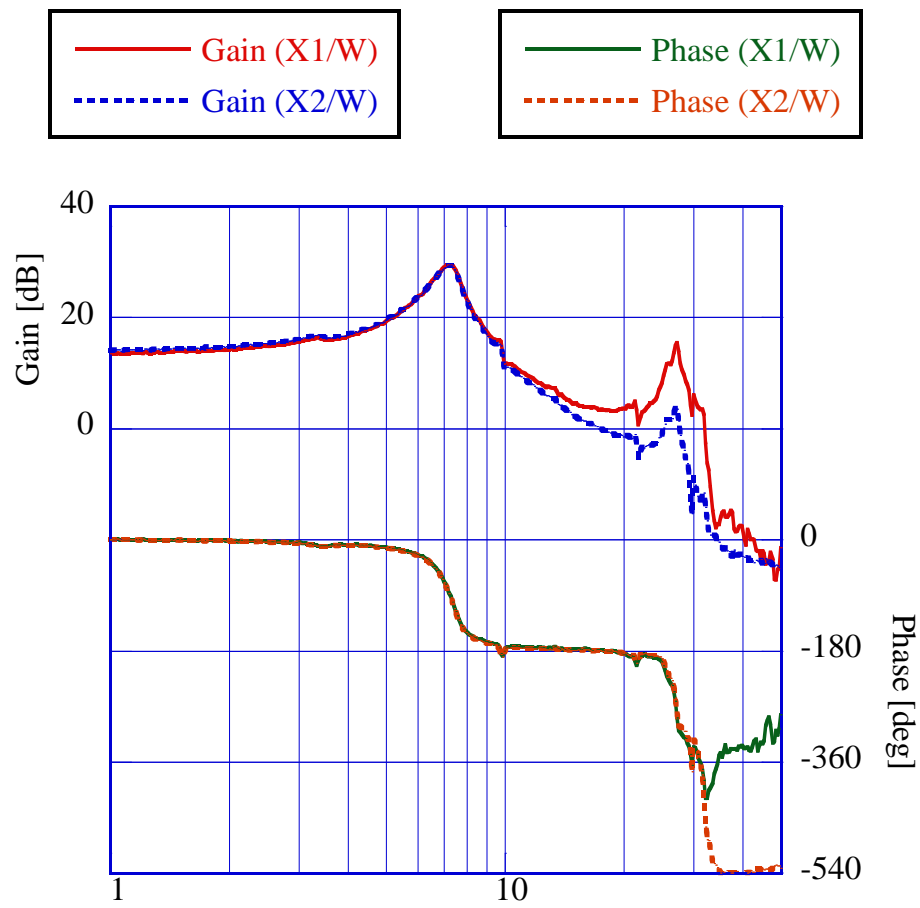

Frequency $[\mathrm{Hz}]$

Fig. 6 Frequency responses. The response of each displacement $(\mathrm{Xn})$ to disturbance $(\mathrm{W})$ are shown. This system has two resonant frequency in $7.3 \mathrm{~Hz}$ and $27.3 \mathrm{~Hz}$. At the second peak, the gain of X2/W is $12 \mathrm{~dB}$ less than that of X1/W. In addition, in a low-frequency region, both suspended points vibrate in common phase with respect to the disturbance. 
のことから，一つ目の共振周波数付近ではほぼ回転運動を伴わない並進運動となっており，二つ目の共振周波数 付近では並進運動及び同周期の回転運動が重なりあって振動していると推察される.すなわち, 実際には回転運 動によって各支持部が逆位相となるモードが発生していても，同時に並進運動を伴っていることで，各支持部の 運動は変位センサから見ると同位相となっているように見えると考えられる. なお， $30 \mathrm{~Hz}$ 付近で位相に差が出 始めるが，このときのゲインから変位は $1 \mu \mathrm{m}$ 以下となっていることから，今回の実験構成ではこの領域の周波 数応答を正確に測定できていないものと判断した．より高周波での測定は今後の課題となっている.

\section{5. 結 言}

単一の浮上体の多自由度の運動を制御するシステムに並列多重磁気浮上を適用した. 2 自由度磁気浮上系のモ デルを対象として理論解析を行い, 並列多重磁気浮上を適用したときの可制御条件を導出した. 鉛直並進方向及 び水平軸周りの回転運動を差動型電磁石で制御する 2 自由度磁気浮上装置を製作し, 浮上を実現した. 本装置に おける第 2 支持部の外乱用電磁石を用いてステップ応答及び周波数応答を取得し, 低周波の調和外乱に対して二 つの支持部が同位相で振動することがわかった。

\section{文献}

Beams, J. W., Magnetically suspended vacuum-type ultracentrifuge, Review of Scientific Instruments, Vol.22, No.2 (1951), pp.77-80.

Henrikson, C. H., Lyman, J. and Studer, P. A., Magnetically suspended momentum wheel for spacecraft stabilization, AIAA 12th Aerospace Sciences Meeting, No. 74-128 (1974), pp. 1-9.

Masuzawa, T., Onuma, H., Kim, S. J. and Okada, Y., Magnetically suspended centrifugal blood pump with a self-bearing motor, ASAIO Journal, Vol.48 (2002), pp.437-442.

水野毅, 高崎正也, 石野裕二, 多重式磁気浮上システムの開発（第 1 報 : 基本構想）, 日本機械学会論文集 C 編, Vol.76, No.761 (2010), pp.76-83.

Morishita, M., Azukizawa, T., Kanda, S., Tamura, N. and Yokoyama, T., A new maglev system for magnetically levitated carrier system, IEEE Transactions on Vehicular Technology, Vol. 38, No. 4 (1989), pp.230-236.

成澤慶宜, 高崎正也, 石野裕二, 水野毅, 電圧制御型並列接続式並列二重磁気浮上におけるゼロパワー制御の実 現, モータドライブルニアドライブ合同研究会電気学会研究会資料, MD-12-063 077 (2012), pp. 75-78.

Nishimura, K., Mizuno, T., Takasaki, M. and Ishino, Y., Realization of voltage-controlled parallel magnetic suspension system, Proceedings of the 20th MAGDA Conference (2011), pp.79-84.

岡宏一, 中村豪太, 岡崎大洋, 鶴見輝, 孫鳳, 可変磁路制御形 2 自由度浮上機構一 2 つ鉄球の浮上と棒の浮上に おける考察, 第 54 回自動制御連合講演会講演論文集 (2011), pp.1268-1271.

Sabnis, A. V., Dendy, J. B. and Shumitt, F. M., A magnetically suspended large momentum wheel, Journal of Spacecraft and Rockets, Vol.12, No.7 (1975), pp.420-427.

櫻田巧, 水野毅, 高崎正也, 石野裕二, 多重式磁気浮上システムの開発（第 2 報 : 並列 2 重磁気浮上の実現）, 日 本機械学会論文集 C 編, Vol.77, No.779 (2011), pp.119-129.

孫鳳, 岡宏一, 円盤磁石を用いた可変磁路制御機構による磁気浮上（二つの鉄球同時浮上実験），日本機械学会論 文集 C 編, Vol.78, No.792 (2012), pp.2771-2780.

電気学会 磁気浮上応用技術調査専門委員会 編, 磁気浮上と磁気軸受(1993), pp.34-36.

\section{References}

Beams, J. W., Magnetically suspended vacuum-type ultracentrifuge, Review of Scientific Instruments, Vol.22, No.2 (1951),pp.77-80.

Henrikson, C. H., Lyman, J. and Studer, P. A., Magnetically suspended momentum wheel for spacecraft stabilization, AIAA 12th Aerospace Sciences Meeting, No. 74-128 (1974), pp. 1-9.

Masuzawa, T., Onuma, H., Kim, S. J. and Okada, Y., Magnetically suspended centrifugal blood pump with a self-bearing motor, ASAIO Journal, Vol.48 (2002), pp.437-442.

Mizuno, T., Takasaki, M. and Ishino, Y., Multiple magnetic suspension systems (1st report: Basic concepts and theorems), 
Transactions of the Japan Society of Mechanical Engineers, Series C, Vol.76, No.761 (2010) pp.76-83 (in Japanese).

Morishita, M., Azukizawa, T., Kanda, S., Tamura, N. and Yokoyama, T., A new maglev system for magnetically levitated carrier system, IEEE Transactions on Vehicular Technology, Vol. 38, No. 4 (1989), pp.230-236.

Narisawa, Y., Takasaki, M., Ishino, Y. and Mizuno, T., Realization of zero-power control in a voltage-controlled double parallel suspension system with parallel connection, The paper of Technical Meeting on MD IEE Japan, MD-12-063 077 (2012), pp. 75-78 (in Japanese).

Nishimura, K., Mizuno, T., Takasaki, M. and Ishino, Y., Realization of voltage-controlled parallel magnetic suspension system, Proceedings of the 20th MAGDA Conference (2011), pp.79-84.

Oka, K., Nakamura, G., Okazaki, T., Tsurumi, A. and Sun, F., Magnetic suspension system using variable flux pat control mechanism - Study of simultaneous 2 ball system and stick type object system - , The 54th Japan Joint Automatic Control Conference (2011), pp.1268-1271 (in Japanese).

Sabnis, A. V., Dendy, J. B. and Shumitt, F. M., A magnetically suspended large momentum wheel, Journal of Spacecraft and Rockets, Vol.12, No.7 (1975), pp.420-427.

Sakurada, T., Mizuno, T., Takasaki, M. and Ishino, Y., Multiple magnetic suspension systems (2nd report: realizing double parallel magnetic suspension), Transactions of the Japan Society of Mechanical Engineers, Series C, Vol.77, No.779 (2011), pp.119-129 (in Japanese).

Sun, F. and Oka, K., Magnetic suspension using variable flux path control mechanism with permanent magnet (Simultaneous suspension experiment of two iron balls), Transactions of the Japan Society of Mechanical Engineers, Series C, Vol.78, No.792 (2012), pp.2771-2780 (in Japanese).

The Magnetic Levitation Technical Committee of The Institute of Electrical Engineers of Japan ed., Magnetic Suspension Technology - Magnetic Levitation Systems and Magnetic Bearings - (1993), pp.34-36 (in Japanese). 